\title{
Comparative Studies on the Disease Prevalence and Population Dynamics of Ginger Blotch and Brown Blotch Pathogens of Button Mushrooms
}

\author{
Tanvi Taparia, ${ }^{1,2}$ Ed Hendrix, ${ }^{1}$ Marc Hendriks, ${ }^{1}$ Marjon Krijger, ${ }^{1}$ Wietse de Boer, ${ }^{1,2}$ and Jan van der Wolf ${ }^{1, \dagger}$ \\ ${ }^{1}$ Biointeractions and Plant Health, Wageningen University and Research, Wageningen 6708PB, The Netherlands \\ ${ }^{2}$ Department of Microbial Ecology, Netherlands Institute of Ecology, Wageningen 6708PB, The Netherlands
}

Abstract

\begin{abstract}
Bacterial blotch is one of the most economically important diseases of button 'mushroom. Knowledge of mechanisms of disease expression, inoculum thresholds, and disease management is limited to the most wellknown pathogen, Pseudomonas tolaasii. Recent outbreaks in Europe have been attributed to ' $P$. gingeri' and $P$. salomonii for ginger and brown blotch, respectively. Information about their identity, infection dynamics, and pathogenicity is largely lacking. The disease pressure in an experimental mushroom cultivation facility was evaluated for ' $P$. gingeri' and $P$. salomonii over varying inoculation densities, casing soil types, environmental humidity, and cultivation cycles. The pathogen population structures in the casing soils were simultaneously tracked across the cropping cycle using highly specific and sensitive TaqMan-quantitative PCR assays. ' $P$. gingeri' caused disease outbreaks at lower inoculum thresholds $\left(10^{4} \mathrm{CFU} / \mathrm{g}\right)$ in the soil than $P$. salomonii $\left(10^{5} \mathrm{CFU} / \mathrm{g}\right)$. Ginger blotch generically declined in
\end{abstract}

later harvest cycles, although brown blotch did not. Casing soils were differentially suppressive to blotch diseases, based on their composition and supplementation. Endemic pathogen populations increased across the cultivation cycle although the inoculated pathogen populations were consistent between the first and second flush. In conclusion, ' $P$. gingeri' and $P$. salomonii have unique infection and population dynamics that vary over soil types. Their endemic populations are also differently abundant in peatbased casing soils. This knowledge is essential for interpreting diagnostic results from screening mushroom farms and designing localized disease control strategies.

Keywords: Agaricus bisporus, casing soil, dose response, pathogenicity, Pseudomonas 'gingeri', Pseudomonas salomonii, soil-borne pathogens, soil inoculum, TaqMan-qPCR
Bacterial blotch is one of the most economically important diseases in the cultivation of the common button mushroom, Agaricus bisporus (Osdaghi et al. 2019; Soler-Rivas et al. 1999). Bacterial blotch is a group of diseases that cause rapid and superficial discoloration of the mushroom cap. This causes yield losses during mushroom cultivation due to reduced aesthetic market value and reduced postharvest shelf life (Fermor et al. 1991; Wells et al. 1996). Various Pseudomonas spp. from casing soil (a peat-based growing medium) are described to cause bacterial blotch on mushroom caps (Fletcher et al. 1989).

Of these, Pseudomonas tolaasii is the most well-known pathogen of "brown blotch" (Tolaas 1915). Its phenotypic variation, symptomatic disease expression, biosynthesis of toxin tolaasin, and genetic regulation have been well studied (Grewal et al. 1995; Han et al. 1994; Rainey et al. 1993). However, the characterization, epidemiology, and regulation of other known blotch pathogens such as ' $P$. gingeri', 'P. reactans', $P$. costantinii, and $P$. fluorescens have received

${ }^{\dagger}$ Corresponding author: J.van der Wolf; jan.vanderwolf@wur.nl

Funding: This project was granted by the Topsector Horticulture and propagation material of the Dutch Ministry of Economic Affairs, conducted under grant number KV1509-050 in collaboration with members of the Dutch and Belgian mushroom supply chain.

*The $\boldsymbol{e}$-Xtra logo stands for "electronic extra" and indicates that supplementary figures are published online.

The author(s) declare no conflict of interest.

Accepted for publication 1 October 2020.

This article is in the public domain and not copyrightable. It may be freely reprinted with customary crediting of the source. The American Phytopathological Society, 2021. limited attention thus far. Recent disease outbreaks in Western Europe led to the discovery of $P$. salomonii, $P$. edaphica, and $P$. yamanorum as other brown-blotch-causing pathogens (Taparia et al. 2020a).

' $P$. gingeri' is one of the only known causative agents of "ginger blotch" (Wong et al. 1982). It produces ginger-colored discolorations on mushroom caps that lead to crop loss during the growth cycle and postharvest (Wells et al. 1996). On King's B medium, 'P. gingeri' produces mucoid colonies that are fluorescent under UV light. It is characterized by glucose assimilation on HL medium, poor hydrolysis of starch and gelatin, decomposition of distilled citrate, and lack of levan production from sucrose, and is oxidase and catalase positive (Szumigaj-Tarnowska et al. 2010). Biochemically, it differs from brown blotch pathogens in the ability to produce levan and spectrum of carbon source utilization (Wells et al. 1996). 'P. gingeri' also does not exude the toxin tolaasin (Lee et al. 2002).

$P$. salomonii was first identified as a clove-borne pathogen of "Café au lait" disease on garlic, which is transmitted via planting material (Gardan et al. 2002; Jacques et al. 2009). It was recently identified as a brown blotch pathogen of button mushroom, A. bisporus, on the basis of genetic and phenotypic tests (Taparia et al. 2020a, b). On King's B medium, $P$. salomonii forms small, semimucoid, opaque, and nonfluorescent colonies, with morphological properties similar to those of P. tolaasii (Cutri et al. 1984). It is characterized biochemically by a hypersensitive response on tobacco, hydrolysis of aesculin and gelatin, levan production, and nitrate reduction and agglutination of a specific polyclonal antiserum (Gardan et al. 2002; Samson 1982).

In this research, we focus on aggressive strains of ' $P$. gingeri' (IPO3777) and $P$. salomonii (IPO3765), which were isolated from symptomatic mushroom tissue during a blotch outbreak of 2015 in The Netherlands (Taparia et al. 2020a). They cause bacterial blotch symptoms when inoculated on fresh mushroom caps and in casing soils. Highly specific and sensitive TaqMan-quantitative PCR 
(qPCR) assays were recently developed for the molecular detection of ' $P$. gingeri' and $P$. salomonii. The assays can detect 10 copies of pathogen DNA using gBlocks, $10^{3}$ cells $/ \mathrm{ml}$ of pathogen in water samples, and $10^{4}$ cells/g of pathogen in soil samples (Taparia et al. $2020 \mathrm{~b})$. In a large-scale sampling of mushroom farms in The Netherlands and Belgium, ' $P$. gingeri' and $P$. salomonii were present on 78 and $42 \%$ of the blotched mushrooms, respectively, indicating large local presence of both pathogens (Taparia et al. 2020b).

In this study, we report the disease prevalence and population dynamics of this newly discovered brown blotch pathogen, $P$. salomonii (IPO3765), in comparison with that of the ginger blotch pathogen, ' $P$. gingeri' (IPO 3777), in cultivation experiments which mimic the conditions of commercial mushroom cropping systems. In addition, we studied the relationship between pathogen populations in the casing soil and the bacterial blotch prevalence in the crop using quantitative detection assays. We also explored the role of abiotic and biotic indicators such as environmental humidity and casing soil type on the blotch prevalence.

\section{Materials and Methods}

General set-up of cultivation bioassay. In an experimental mushroom cultivation facility (Unifarm, Wageningen University and Research), the conditions of commercial mushroom farms were mimicked. Plastic packaging boxes (dimensions of 40 by 50 by $23 \mathrm{~cm}$ [length by width by height]) with closed sides and bottom and a growing surface of $0.2 \mathrm{~m}^{2}$ were used as mushroom beds. The experiment consisted of 128 boxes, arranged across two stands over five vertical layers in a randomized block design, with four replicates per treatment.

Two types of casing soils containing different types of peat and amendments were prepared (Supplementary Fig. S1). Each box was filled with $8.5 \mathrm{~kg}$ of compost fully colonized with A. bisporus strain A15 (Sylvan). Then, 5 liters of casing soil inoculated with phase III compost at $100 \mathrm{~g} / \mathrm{kg}$ (a process called "cac-ing") was applied on top. The growing chamber was allowed to vent, reducing the temperature from 24 to $18^{\circ} \mathrm{C}$ by $1^{\circ} \mathrm{C} /$ day until the first pinheads developed. The mushrooms were allowed to grow further at $18^{\circ} \mathrm{C}$ with $\mathrm{CO}_{2}$ at $1,100 \mathrm{ppm}$ and two different relative humidity $(\mathrm{RH})$ conditions (90 and 95\% RH). Weight and numbers of healthy and diseased mushrooms harvested from each unit were registered daily across two cultivation cycles, called flushes. Disease prevalence was calculated as a percentage of the diseased harvest weight to the total harvest weight across all three flushes.

Inoculation of blotch pathogens. Effects of two blotch pathogens on disease pressure and productivity of the cultivation system were observed for a range of biotic and abiotic conditions (Table 1). Pathogenic strains of 'P. gingeri' (IPO3777) and P. salomonii (IPO 3765) (Taparia et al. 2020b) were grown on King's B medium (King et al. 1954) for $24 \mathrm{~h}$ at $28^{\circ} \mathrm{C}$. The virulence of the plated isolates was

Table 1. Experimental design of bioassay where blotch prevalence and pathogen populations were recorded over varying biotic and abiotic factors described below

\begin{tabular}{lc}
\hline Bioassay & Description \\
\hline $\begin{array}{l}\text { Experimental factors } \\
\text { Casing soil type }\end{array}$ & Two different compositions of casing: \\
soil A and soil B \\
Ppecies of pathogen: 'Pseudomonas \\
gingeri' and $P$. salomonii \\
Inoculation density & Inoculation density of pathogen: 0, \\
& $10^{4}, 10^{5}$, and $10^{6}$ CFU/g of soil \\
Environmental humidity & Relative air humidity: 90 and $95 \%$ \\
Flush & Progressive cultivation cycle: first \\
& flush and second flush \\
Measurements & Percentage of diseased harvest/total \\
Blotch prevalence & harvest (wt/wt) \\
Pathogen population & Estimated density from quantitative \\
& PCR relative to Xanthomonas \\
campestris (cells/g)
\end{tabular}

retested in an in vitro pathogenicity assay on fresh mushroom caps. Bacterial suspension of $10^{8}$ cells $/ \mathrm{ml}$ (optical density at $600 \mathrm{~nm}=$ 0.1 ) was made from the pathogen cultures in sterile Ringer's solution (Thermo Fisher Scientific, Germany). For the bioassay, diluted pathogen suspensions were inoculated evenly by watering across the growing surface of the casing soil (after cac-ing) at densities of $10^{4}, 10^{5}$, and $10^{6} \mathrm{CFU} / \mathrm{g}$ wet weight of soil. The pathogen suspensions used for inoculation were also dilution plated on King's B medium for colony counting. The negative control comprised mushroom beds supplemented with equivalent amount of Ringer's solution (Thermo Fisher Scientific, Germany).

Soil sampling and DNA extraction. Casing soil ( $1 \mathrm{~g})$ was sampled from the top soil with a spatula from each box 4 days after cac-ing (T0), at pinhead formation of first flush (T1), and at pinhead formation of second flush (T2), which correspond to 0,7 , and 14 days post pathogen inoculation, respectively. The mushroom pinheads were avoided during the soil sampling. Homogenized soil (250 mg) was used for DNA extraction using a Soil PowerMag DNA Extraction kit (Qiagen, Germany) according to the manufacturer's protocol. A Xanthomonas campestris pv. campestris suspension of $10^{5}$ cells was added to each soil sample as an extraction control, before the DNA extraction. The soil DNA was quantified fluorometrically using a Quant-iT PicoGreen dsDNA Assay Kit (Thermo Fisher Scientific, United States) according to the manufacturer's protocol on the Infinite M200 PRO (Tecan, Switzerland), then diluted to a concentration of $2 \mathrm{ng} / \mu \mathrm{l}$.

Quantification of pathogen populations. Detection of bacterial DNA in soil samples was performed using the TaqMan probe technology, on a QuantStudio 12K Flex from Applied Biosystems (Thermo Fisher Scientific, United States). Assays Pg2 and Pg6 were used to detect ' $P$. gingeri', assays $\mathrm{Pu} 4$ and $\mathrm{Pu} 10$ were used to detect $P$. salomonii, and assay Xcc was used to detect the extraction control $X$. campestris pv. campestris. The sequence of the primers and probes are described by Taparia et al. (2020b).

qPCR was performed with $2 \mathrm{ng}$ of soil DNA, according to previously reported protocol and reaction conditions (Taparia et al. $2020 \mathrm{~b})$. A threshold cycle $\left(\mathrm{C}_{\mathrm{T}}\right)$ value lower than 40 was considered a positive reaction (Supplementary Fig. S2). Pathogen populations in the soil were quantified relative to known densities of $X$. campestris pv. campestris. Fold-change ratios were calculated from the $C_{T}$ values by the $2^{-\Delta \Delta C T}$ method (Livak and Schmittgen 2001). Estimated pathogen populations in the soil were reported in cells per gram, by multiplying the fold-change ratio with inoculation density of $X$. campestris pv. campestris.

Data analysis. Statistical analysis was performed on RStudio with $R$ version 3.4.0 ( $R$ Core Team 2013). Threshold cycle $\left(C_{T}\right)$ values from TaqMan-qPCR experiments were imported from QuantStudio Software v1.3 (Life Technologies). Bioassay and qPCR observations were organized using tidyverse (Wickham et al. 2019). The effect of casing soil type, pathogen type, inoculated pathogen density, and harvest cycle on blotch prevalence and pathogen populations was studied using analysis of variance (ANOVA) (Chambers et al. 2017). Model assumptions such as normality of data and homogeneity of variance were tested using diagnostic plots and statistical tests (Fox et al. 2012). Pathogen population and blotch prevalence were plotted via ggplot2 (Wickham et al. 2016). Error bars in all figures
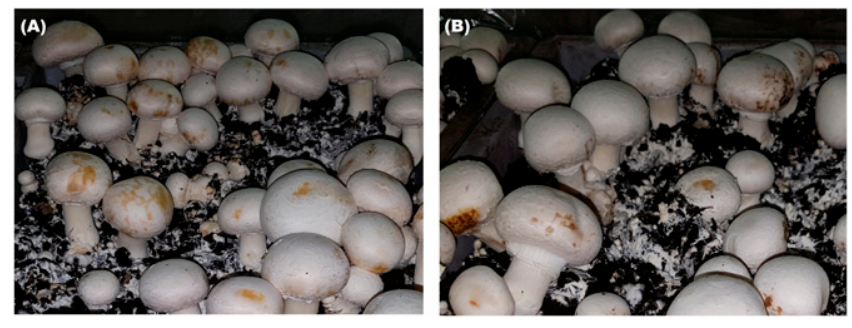

Fig. 1. Bacterial blotch symptoms on Agaricus bisporus in a bioassay when inoculated with A, 'Pseudomonas gingeri' isolate IPO3777 and B, P. salomonii isolate IPO3765 at a density of $10^{6} \mathrm{CFU} / \mathrm{g}$ of casing soil. 
represent the standard error of the mean, calculated over a sample size of 20 per treatment (pathogen strain, pathogen density, and soil type) for the bioassay data and sample size of 27 per treatment for the qPCR data.

\section{Results}

Disease prevalence of ginger and brown blotch. In the cultivation bioassay, both pathogens caused visible symptoms that could be distinguished for quantification of blotch prevalence. ' $P$. gingeri' produced ginger-colored discolorations that were spread over a large surface area whereas $P$. salomonii produced dark-brown discolorations over multiple irregular spots, often accompanied by pitting (Fig. 1). Bacterial blotch prevalence in the cropping system was significantly affected by the pathogen type, inoculated pathogen density, casing soil type, harvest cycle (flush), and their interactions. Increased environmental humidity did not have a significant effect on bacterial blotch in the bioassay. The $P$ values and estimates from the ANOVA are described in Table 2. It also met statistical assumptions on normal distribution and homogeneity of variance.

For the control mushroom beds, in the absence of inoculated pathogen, the mean ginger blotch and brown blotch prevalence were similar at $2.9 \pm 0.8$ and $2.3 \pm 0.7 \%$, respectively. In the inoculated mushroom beds, the mean bacterial blotch prevalence increased with inoculation density but the effect was pathogen specific (Fig. 2). At the lowest inoculation density $\left(10^{4} \mathrm{CFU} / \mathrm{g}\right)$, the ginger blotch prevalence $(14.3 \pm 1.8 \%)$ was much higher than the brown blotch prevalence $(5.0 \pm 0.9 \%)$. Despite differences between the pathogens, their blotch prevalence was found to be similar at the higher inoculation densities. At the highest density $\left(10^{6} \mathrm{CFU} / \mathrm{g}\right)$, ginger and brown blotch prevalence were observed at $22.3 \pm 2.4$ and $19.1 \pm 2.1 \%$, respectively.

The disease prevalence of the pathogens was different for the two casing soils tested (Fig. 2). In the control mushroom beds, the inherent blotch prevalence of casing soil A $(3.5 \pm 0.9 \%)$ was higher than that of casing soil B $(1.7 \pm 0.5 \%)$. In the inoculated mushroom beds, the mean blotch prevalence in casing soils A and B increased to 11.0 \pm 1.1 and $18.8 \pm 1.1 \%$, respectively. When inoculated in casing soil A, 'P. gingeri' and $P$. salomonii had similar blotch prevalence but, in casing soil $\mathrm{B}$, the mean ginger and brown blotch prevalence was 21.1 \pm 1.4 and $16.5 \pm 1.8 \%$, respectively.

Bacterial blotch prevalence also followed a temporal effect across the cultivation cycle which was pathogen specific (Fig. 3). In the absence of inoculated pathogen, the inherent blotch prevalence remained low and constant across multiple cultivation cycles. In the inoculated samples, the mean brown blotch prevalence was consistent across both of the harvest cycles (flushes) at $14.7 \pm 1.8$ and 13 $\pm 1.7 \%$ but the mean ginger blotch prevalence declined strongly with consecutive harvest cycles, from $20.1 \pm 1.6 \%$ in the first flush to 11.9 $\pm 1.4 \%$ in the second flush.

Population dynamics of ' $P$. gingeri' and $P$. salomonii. Quantitative TaqMan-qPCR assays Pg2 and Pg6 were used to track ' $P$. gingeri' populations in the casing soil over three time points in the cultivation cycle: $\mathrm{T} 0, \mathrm{~T} 1$, and $\mathrm{T} 2$. Casing soil samples were similarly quantified for presence of $P$. salomonii, using the diagnostic TaqMan-qPCR assays Pu4 and Pu10. The estimated populations of ' $P$. gingeri' and $P$. salomonii in the soil were significantly affected by inoculation of pathogen, casing soil type, and time point of the cultivation cycle (flush). The $P$ values and estimates from the ANOVA are described in Table 3. It also met statistical assumptions on normal distribution and homogeneity of variance.

For control mushroom beds, in the absence of inoculated pathogen, ' $P$. gingeri' populations were undetectable at T0 and T1. However, at T2, the estimated pathogen population of ' $P$. gingeri' in the soil was $3.5 \pm 2.2 \times 10^{5}$ cells/g (Fig. $4 \mathrm{~A}$ ). When the mushroom beds were inoculated with ' $P$. gingeri' at $10^{6}$ cells/g, the pathogen was detectable immediately. Within the inoculated soils, the estimated
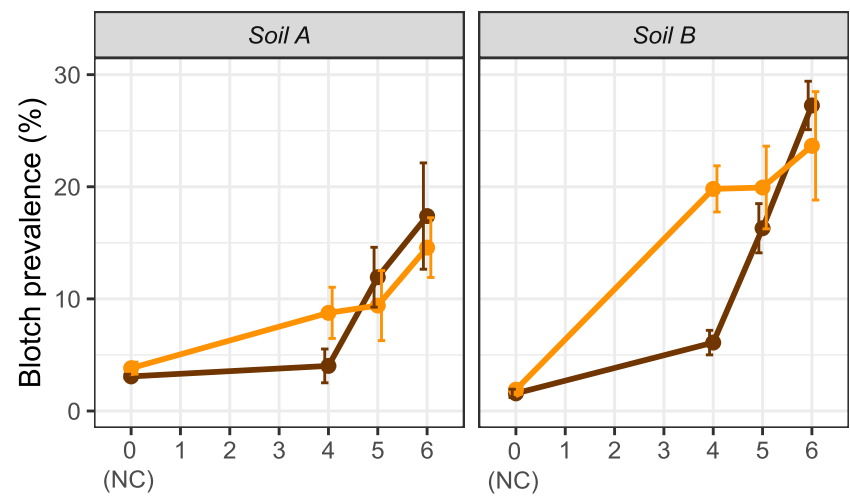

Inoculated pathogen density $\left(10^{x} \mathrm{cfu} / \mathrm{g}\right)$

Pathogen $\rightarrow$ P. salomonii $=-$ 'P. gingeri'

Fig. 2. Effect of two different types of casing soils on the mean bacterial blotch prevalence of 'Pseudomonas gingeri' and $P$. salomonii on Agaricus bisporus over varying inoculation densities.

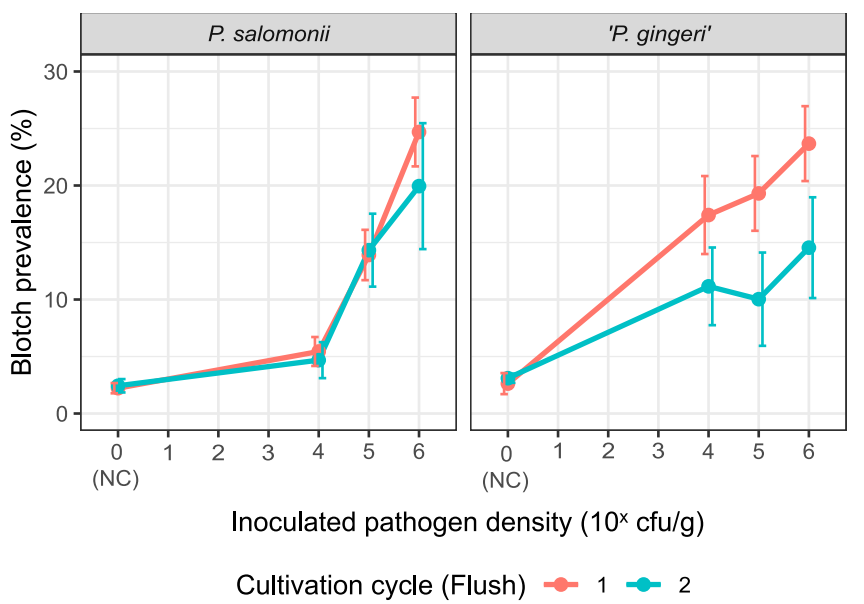

Fig. 3. Effect of two consecutive harvest cycles (flushes) on the mean bacterial blotch prevalence of 'Pseudomonas gingeri' and $P$. salomonii on Agaricus bisporus over varying inoculation densities.

Table 2. Univariate analysis of variance (ANOVA) of bacterial blotch prevalence recorded in the bioassay ${ }^{\mathrm{a}}$

\begin{tabular}{lcccccc}
\hline Experimental factors & Df & Sum Sq & Mean Sq & $\boldsymbol{F}$ statistic & $\boldsymbol{P}(>\boldsymbol{F})$ & Sig \\
\hline Inoculation density & 1 & 1.34 & 1.34 & 140.504 & 0.00000 & $* .00236$ \\
Pathogen type & 1 & 0.09 & 0.09 & 9.436 & $* .461$ & 0.02024 \\
Flush & 1 & 0.0521 & 0.0521 & 4.694 & 0.03123 \\
Casing soil type & 1 & 0.0448 & 0.0448 & 6.769 & 0.00983 & $*$ \\
Casing soil: Flush & 1 & 0.0646 & 0.0646 & 9.29 & 0.00255 \\
Casing soil: Inoculation density & 1 & 0.0886 & 0.0886 & 3.763 & 0.05354 \\
Pathogen type: Flush & 1 & 0.0359 & 0.0359 & $\ldots$ & $\ldots$ \\
Residuals & 248 & 2.3652 & 0.0095 & $\ldots$ & $\ldots$ \\
\hline
\end{tabular}

\footnotetext{
a Degrees of freedom (Df), sum and mean squares (Sq), $F$-test statistic, $P$ values, significance codes (Sig), and residuals from the ANOVA are described.
} 
pathogen population ranged between $3.1 \times 10^{3}$ and $1.2 \times 10^{8}$ cells $/ g$ during the flushes, which indicated spatial heterogeneity in the pathogen populations recovered from the casing soil. Despite this high variation, in the soils inoculated with the pathogen at $10^{6} \mathrm{CFU} / \mathrm{g}$, the estimated population remained largely consistent across $\mathrm{T} 0$, $\mathrm{T} 1$, and $\mathrm{T} 2$ at $2.1 \pm 1.1 \times 10^{5}, 1.9 \pm 0.6 \times 10^{5}$, and $2.2 \pm 1.1 \times 10^{5}$ cells/g, respectively.

In control mushroom beds, which were uninoculated, the estimated population of $P$. salomonii in the soil at T0 was $9.6 \pm 7.4 \times$ $10^{3}$ and $6.2 \pm 6.1 \times 10^{3}$ for casing soils $\mathrm{A}$ and $\mathrm{B}$, respectively. When $P$. salomonii was inoculated in the mushroom beds using a density of $10^{6} \mathrm{CFU} / \mathrm{g}$, the estimated pathogen population increased to $3.0 \pm$ $1.9 \times 10^{4}$ and $4 \pm 0.7 \times 10^{4}$ cells/g in casing soils $\mathrm{A}$ and $\mathrm{B}$, respectively. At T0, T1, and T2, the estimated pathogen populations in inoculated soils increased to $3.5 \pm 0.9 \times 10^{4}, 3.1 \pm 1.3 \times 10^{5}$, and $3.1 \pm$ $0.8 \times 10^{5}$ cells/g, respectively (Fig. 4B). The variation in the estimated pathogen population of the inoculated samples ranged between $6.6 \times 10^{3}$ and $4.8 \times 10^{6}$ cells/g during the cultivation cycle. It reaffirms the non-homogeneous distribution of pathogen population structures in the soil despite uniform application of inoculum.

\section{Discussion}

Soil inoculum threshold. In this study, the disease prevalence and population dynamics of a newly characterized brown blotch pathogen, $P$. salomonii, which is widespread in the Dutch mushroom cultivation ecosystem, have been compared with a ginger blotch pathogen, ' $P$. gingeri', which is responsible for major losses in Western Europe. In cultivation bioassays, $P$. salomonii and ' $P$. gingeri' demonstrated different inoculum thresholds for blotch outbreaks. ' $P$. gingeri' caused blotch outbreaks at an inoculum density of $10^{4}$ $\mathrm{CFU} / \mathrm{g}$ of casing soil, whereas $P$. salomonii caused similar levels of blotch at a 10 -fold higher inoculation density of $10^{5} \mathrm{CFU} / \mathrm{g}$ in the soil.

Thus far, information on inoculum thresholds of blotch pathogens has been largely limited to studies on the mushroom cap surface. ' $P$. gingeri' on mushroom caps has been shown to produce symptoms at a density of $1.7 \times 10^{7}$ cells/cap (Soler-Rivas et al. 2000). For brown blotch from $P$. tolaasii, a minimum inoculum density of $7.7 \times 10^{4}$ cells $/ \mathrm{cm}^{2}$ of mushroom cap surface for symptomatic disease expression was reported (Nair and Fahy 1972). However, these pathogen detection methods were based solely on plating and colony morphology.

In other bioassays, where $P$. tolaasii was inoculated to the casing soil, a density of $2 \times 10^{6}$ cells/g of soil caused a blotch incidence of 25 to $30 \%$, similar to that in our studies (Grewal 1991). Application of $P$. tolaasii at 20 cells $/ \mathrm{cm}^{2}$ led to $60 \%$ blotch prevalence (Wong and Preece 1982). However, increasing $P$. tolaasii densities to a higher level such as $10^{10}$ cells/g led to a complete crop loss, with $>90 \%$ blotch prevalence (Royse and Wuest 1980). Thus far, not much other information is available on threshold levels for other blotchcausing Pseudomonas spp. in casing soil.

Role of abiotic and biotic factors. The disease prevalence of the pathogens differed between the two harvest cycles (flushes) when inoculated to the casing soils. Despite reduced ginger blotch prevalence in the second flush, ' $P$. gingeri' populations recovered from the soil remained consistent between $\mathrm{T} 1$ and $\mathrm{T} 2$. In personal communication, Dutch mushroom growers shared similar observations about the reduced susceptibility of later flushes to ginger blotch. This natural suppression of ginger blotch and its microbial ecology needs further exploration. Interestingly, mushrooms from the second flush have also been reported to have less yellow discoloration from bruising than those of the first flush (Burton and Noble 1993). However, this was attributed to the postharvest physiology of the mushroom. In the case of brown blotch, both flushes were equally susceptible. This was also reported in bioassays for brown blotch caused by $P$. tolaasii (Royse and Wuest 1980).

The bacterial blotch prevalence of both pathogens also differed between the two types of casing soils. In uninoculated samples, the blotch prevalence of casing soil A was higher than that of soil B. The endemic pathogen populations in casing soil A were also higher. However, when the pathogens were inoculated, casing soil B had slightly higher brown bacterial blotch prevalence compared with soil A, which was also reflected in the increased $P$. salomonii populations recovered from casing soil $\mathrm{B}$. The ginger blotch prevalence of soil $\mathrm{B}$ was significantly higher than that of soil A, although the estimated

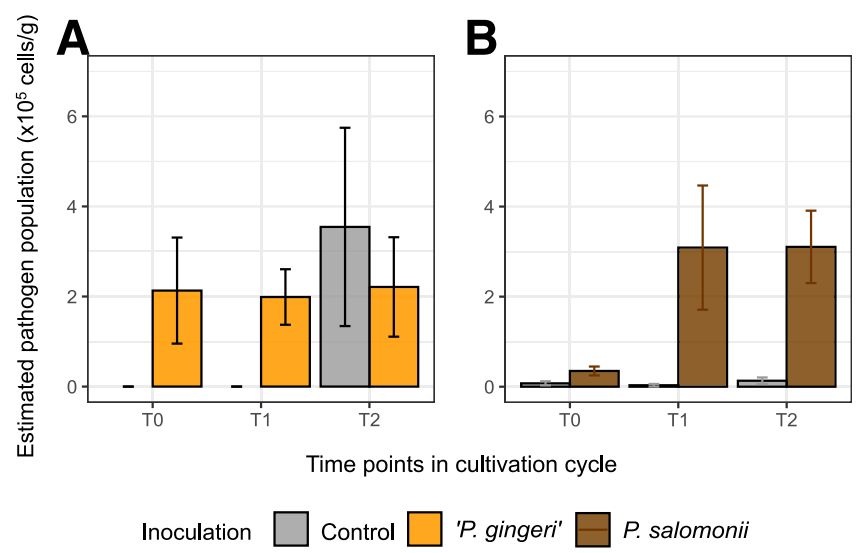

Fig. 4. Bar plots describing the estimated pathogen populations of $\mathbf{A}$, 'Pseudomonas gingeri and $\mathrm{B}, P$. salomonii in control and inoculated mushroom beds across the cultivation cycle, derived from TaqMan-quantitative PCR assays on casing soil samples from the bioassay.

Table 3. Multivariate analysis of variance (MANOVA) of pathogen populations in the casing soil during the bioassay, based on threshold cycle $\left(\mathrm{C}_{\mathrm{T}}\right)$ values obtained from diagnostic TaqMan-quantitative PCR assays ${ }^{\mathrm{a}}$

\begin{tabular}{|c|c|c|c|c|c|c|}
\hline Experimental factors & Df & Sum Sq & Mean Sq & $F$ statistic & $P(>F)$ & Sig \\
\hline \multicolumn{7}{|l|}{ 'Pseudomonas gingeri' populations } \\
\hline Time (flush) & 2 & 202.3 & 101.1 & 6.18 & 0.00352 & $* *$ \\
\hline Inoculation of pathogen & 1 & 983 & 983 & 60.057 & 0.00000 & $* * *$ \\
\hline Inoculation density: Time & 2 & 481.7 & 240.8 & 14.714 & 0.00001 & $* * *$ \\
\hline Casing soil & 1 & 7.2 & 7.2 & 0.442 & 0.50862 & $\ldots$ \\
\hline Inoculation density: Casing soil & 1 & 4.2 & 4.2 & 0.255 & 0.61513 & $\ldots$ \\
\hline Residuals & 64 & $1,047.6$ & 16.4 & $\ldots$ & $\ldots$ & $\ldots$ \\
\hline \multicolumn{7}{|l|}{ P. salomonii populations } \\
\hline Casing soil & 1 & 161.3 & 161.3 & 11.594 & 0.00115 & $* *$ \\
\hline Inoculation of pathogen & 1 & 942.6 & 942.6 & 67.765 & 0.00000 & $* * *$ \\
\hline Inoculation density: Casing soil & 1 & 137.1 & 137.1 & 9.857 & 0.00256 & $* *$ \\
\hline Time (flush) & 2 & 31.9 & 16 & 1.147 & 0.32388 & $\ldots$ \\
\hline Inoculation density: Time & 2 & 51.8 & 25.9 & 1.863 & 0.16358 & $\ldots$ \\
\hline Residuals & 64 & 890.3 & 13.9 & $\ldots$ & $\ldots$ & $\ldots$ \\
\hline
\end{tabular}

${ }^{a}$ Degrees of freedom (Df), sum and mean squares (Sq), $F$-test statistic, $P$ values, significance codes (Sig), and residuals from the MANOVA are described. 
density of ' $P$. gingeri' was not significantly different between both the casing soil types. It is also interesting to note that, at higher pathogen populations, casing soil $\mathrm{A}$ is more suppressive to bacterial blotch than soil B.

Increased environmental humidity did not cause higher bacterial blotch for either pathogens in the bioassay. Blotch development is known to be induced at high environmental humidity due to condensation of water on the mushroom caps, although this effect is rather inconsistent between reports (Navarro et al. 2018; Soler-Rivas et al. 1999; Wong and Preece 1982). The absence of proper ventilation and temperature fluxes influence the rate of condensation and, consequently, blotch development (Wuest 1971). Thus, in a wellventilated climate room as in our bioassay chamber, where the air temperature does not change abruptly, blotch prevalence could be unaffected by a higher $\mathrm{RH}$.

Prediction of blotch prevalence depends on a variety of abiotic and biotic factors. It is essential to understand the impact and interaction between these factors because the risk for disease outbreak does not depend only on pathogen populations in the soil but also on casing soil type, harvest cycle (flush), cultivar or variety, harvesting system, environmental conditions during cultivation, and interactions with other microorganisms in the casing soil and on mushroom surfaces.

Pathogen population structures. Quantitative and specific diagnostic qPCRs confirmed the endemic presence of both bacterial blotch pathogens in the casing soil. In uninoculated mushroom beds, $P$. salomonii was consistently detected at $\mathrm{T} 0$ in casing soil A, which only contained peat from Friedrichsveen. In casing soil B, which is largely composed of peat from Holriede but also partially Friedrichsveen, $P$. salomonii was detected in only a few of the samples. Hence, the endemic population of brown blotch pathogens largely differed between the casing soils based on their peat source. This information supports earlier findings, where raw peat (before it was mixed into a casing soil) was tested positive for the presence of multiple blotch pathogens (Taparia et al. 2020b; Wong and Preece 1980). It confirms the role of peat-based casing soils as a source of introduction for brown blotch pathogens in mushroom farms. However, other sources of introduction such as the compost cannot be excluded.

Both pathogens were detected at higher densities in inoculated soils with high blotch prevalence than in uninoculated soils. Similar findings were reported for brown blotch bioassays, where $P$. tolaasii was detected in both healthy and diseased beds using plating-based methods. With plating on nonselective media, $P$. tolaasii populations were observed at $10^{7}$ to $10^{8}$ cells/g in diseased beds and 0 to $10^{7}$ cells/ $\mathrm{g}$ in healthy beds (Nair and Fahy 1972). On the basis of colony morphology, $P$. tolaasii was reported at much lower densities in diseased beds (Wong and Preece 1980). However, the lack of specificity in detection methods suggests that these pathogen populations were likely overestimated. Use of diagnostic qPCRs in this study enabled detection of $P$. salomonii at much lower densities in the casing soil. In the case of ' $P$. gingeri', the ginger blotch pathogen was undetectable in uninoculated casing soil until the second flush, which suggests that endemic populations of ' $P$. gingeri' in these casing soils, if present, are even lower than those of $P$. salomonii.

TaqMan-qPCR data confirmed the increase of endemic pathogen populations in uninoculated casing soils from $\mathrm{T} 0$ to $\mathrm{T} 2$ for both ' $P$. gingeri' and $P$. salomonii during the cultivation cycle. This could be due to the increased nutrient availability in consecutive cultivation cycles, in the form of $A$. bisporus mycelium that grows through the casing soil (Godfrey 2003). Endemic populations of the brown blotch pathogen $P$. tolaasii in the casing soil were previously reported to increase with mycelial colonization of the casing soil (Wong and Preece 1982). The pathogen's chemotaxis toward and attachment to the A. bisporus mycelium is also well documented (Grewal and Rainey 1991; Rainey 1991). P. tolaasii populations have also been reported to increase across the cultivation cycle from $5.6 \times 10^{6}$ to $45 \times 10^{6}$ cells $/ g$, although the detection was based on colony morphology only (Royse and Wuest 1980).

The large variation in the estimated pathogen populations from casing soil samples at $\mathrm{T} 1$ and $\mathrm{T} 2$ indicates a rather nonhomogeneous spatial distribution of the pathogens in the casing soils, despite uniform inoculation on the casing surface. This is not unexpected, because the pathogen populations are known to migrate toward food sources such as A. bisporus mycelium (Grewal and Rainey 1991). An extensive sampling strategy can allow more precise and representative measurement of pathogen populations. However, direct translation of estimated pathogen populations in the soil to disease prevalence is not possible. The relationship between pathogen populations and disease outbreaks needs further exploration.

Conclusion. The two blotch-causing pathogens demonstrated different infection dynamics in cultivation experiments. P. salomonii was able to cause severe brown blotch symptoms on mushroom caps of $A$. bisporus when inoculated in peat-based soils at densities of $10^{5} \mathrm{CFU} / \mathrm{g}$ or more, while the inoculum thresholds for ' $P$. gingeri' were lower, at $10^{4} \mathrm{CFU} / \mathrm{g}$. Their blotch prevalence also varied according to the cultivation cycle (flush) and type of casing soil used. Endemic populations of $P$. salomonii in the casing soil were higher than those of ' $P$. gingeri', and they varied in density between the casing soil types. ' $P$. gingeri' populations in the soil remained undetectable until later in the cultivation cycle. This knowledge regarding disease prevalence and population dynamics of bacterial blotch pathogens can form a basis for interpreting diagnostic results generated from screening raw materials and processes involved in the mushroom-cropping chain. It generates a better understanding of the microbial ecology of the pathogens in the mushroom cropping cycle, with implications for the design of localized disease control strategies.

\section{Acknowledgments}

We thank K. Pelgrom, J. Baars, J. Amsing, and C. van der Horst for their support in carrying out this research.

\section{Literature Cited}

Burton, K. S., and Noble, R. 1993. The influence of flush number, bruising and storage temperature on mushroom quality. Postharvest Biol. Technol. 3:39-47.

Chambers, J. M., Freeny, A. E., and Heiberger, R. M. 2017. Analysis of variance; designed experiments. Pages 145-193 in: Statistical Models in S. T. J. Hastie, ed. Routledge, New York, NY, U.S.A

Cutri, S. S., Macauley, B. J., and Roberts, W. P. 1984. Characteristics of pathogenic non-fluorescent (smooth) and non-pathogenic fluorescent (rough) forms of Pseudomonas tolaasii and Pseudomonas gingeri. J. Appl. Bacteriol. 57:291-298.

Fermor, T. R., Henry, M. B., Fenlon, J. S., Glenister, M. J., Lincoln, S. P., and Lynch, J. M. 1991. Development and application of a biocontrol system for bacterial blotch of the cultivated mushroom. Crop Prot. 10:271-278.

Fletcher, J. T., White, P. F., and Gaze, R. H. 1989. Mushrooms: Pest and Disease Control, 2nd ed. Intercept, Andover, U.K.

Fox, J., Weisberg, S., Price, B., Adler, D., Bates, D., Baud-Bovy, G., Bolker, B., Ellison, S., Firth, D., Friendly, M., Gorjanc, G., Graves, S., Heiberger, R., Krivitsky, P., Laboissiere, R., Maechler, M., Monette, G., Murdoch, D., Nilsson, H., Ogle, D., Ripley, B., Venables, W., Walker, S., Winsemius, D. and Zeileis, A. 2012. car: Companion to Applied Regression. R Foundation for Statistical Computing, Vienna, Austria.

Gardan, L., Bella, P., Meyer, J.-M., Christen, R., Rott, P., Achouak, W., and Samson, R. 2002. Pseudomonas salomonii sp. nov., pathogenic on garlic, and Pseudomonas palleroniana sp. nov., isolated from rice. Int. J. Syst. Evol. Microbiol. 52:2065-2074

Godfrey, S. A. C. 2003. Molecular investigation of pseudomonads causative of Agaricus bisporus blotch disease in New Zealand mushroom farms. Dissertation, University of Canterbury, Plant and Microbial Sciences.

Grewal, P. S. 1991. Effects of Caenorhabditis elegans (Nematoda: Rhabditidae) on the spread of the bacterium Pseudomonas tolaasii in mushrooms (Agaricus bisporus). Ann. Appl. Biol. 118:47-55.

Grewal, S. I., Han, B., and Johnstone, K. 1995. Identification and characterization of a locus which regulates multiple functions in Pseudomonas tolaasii, the cause of brown blotch disease of Agaricus bisporus. J. Bacteriol. 177:4658-4668.

Grewal, S. I. S., and Rainey, P. B. 1991. Phenotypic variation of Pseudomonas putida and $P$. tolaasii affects the chemotactic response to Agaricus bisporus mycelial exudate. Microbiology 137:2761-2768.

Han, B., Johnstone, K., and Grewal, S. 1994. Regulation of toxin synthesis and phenotypic variation in Pseudomonas tolaasii, cause of brown blotch disease of mushrooms. Pages 25-32 in: Advances in Molecular Genetics of Plant-Microbe Interactions. Current Plant Science and Biotechnology in Agriculture, vol. 21. M. J. Daniels, J. A. Downie, and A. E. Osbourn, eds. Springer, Dordrecht, The Netherlands.

Jacques, M.-A., Luçon, N., and Houdault, S. 2009. Clove-transmissibility of Pseudomonas salomonii, the causal agent of 'Café au lait' disease of garlic. Eur. J. Plant Pathol. 124:695-700. 
King, E. O., Ward, M. K., and Raney, D. E. 1954. Two simple media for the demonstration of pyocyanin and fluorescin. J. Lab. Clin. Med. 44:301-307.

Lee, H., Jeong, K., and Cha, J. 2002. PCR assays for specific and sensitive detection of Pseudomonas tolaasii, the cause of brown blotch disease of mushrooms. Lett. Appl. Microbiol. 35:276-280.

Livak, K. J., and Schmittgen, T. D. 2001. Analysis of relative gene expression data using real-time quantitative PCR and the $2^{-\Delta \Delta C T}$ method. Methods 25:402-408.

Nair, N. G., and Fahy, P. C. 1972. Bacteria antagonistic to Pseudomonas tolaasii and their control of brown blotch of the cultivated mushroom Agaricus bisporus. J. Appl. Bacteriol. 35:439-442.

Navarro, M. J., Gea, F. J., and González, A. J. 2018. Identification, incidence and control of bacterial blotch disease in mushroom crops by management of environmental conditions. Sci. Hortic. (Amsterdam) 229:10-18.

Osdaghi, E., Martins, S., Ramos-Sepulveda, L., Vieira, F. R., Pecchia, J., Beyer, D. M., Bell, T. H., Yang, Y., Hockett, K. L., and Bull, C. T. 2019. 100 Years since Tolaas: Bacterial blotch of mushrooms in the 21st century. Plant Dis. 103:2714-2732.

R Core Team. 2013. R: A language and environment for statistical computing. $R$ Foundation for Statistical Computing, Vienna, Austria. https://www.Rproject.org/.

Rainey, P. B. 1991. Phenotypic variation of Pseudomonas putida and P. tolaasii affects attachment to Agaricus bisporus mycelium. Microbiology 137:2769-2779.

Rainey, P. B., Brodey, C. L., and Johnstone, K. 1993. Identification of a gene cluster encoding three high-molecular-weight proteins, which is required for synthesis of tolaasin by the mushroom pathogen Pseudomonas tolaasii. Mol. Microbiol. 8:643-652.

Royse, D. J., and Wuest, P. J. 1980. Mushroom brown blotch: Effects of chlorinated water on disease intensity and bacterial populations in casing soil and on pilei. Phytopathology 70:902-905.

Samson, R. 1982. Biovar of Pseudomonas fluorescens pathogenic to Allium sativum. In: Proc. Fifth Int. Conf. Plant Pathogenic Bacteria, August 16-23, 1981, Cali, Colombia.

Soler-Rivas, C., Arpin, N., Olivier, J. M., and Wichers, H. J. 2000. Discoloration and tyrosinase activity in Agaricus bisporus fruit bodies infected with various pathogens. Mycol. Res. 104:351-356.

Soler-Rivas, C., Jolivet, S., Arpin, N., Olivier, J. M., and Wichers, H. J. 1999. Biochemical and physiological aspects of brown blotch disease of Agaricus bisporus. FEMS Microbiol. Rev. 23:591-614.
Szumigaj-Tarnowska, J., Oskiera, M., and Szymanski, J. 2010. Pseudomonas gingeri-sprawca plamistości bakteryjnej pieczarki. Zeszyty Problemowe Postępów Nauk Rolniczych [Probl. J. Adv. Agric. Sci.] 554:239-244.

Taparia, T., Krijger, M., Haynes, E., Elphinstone, J. G., Noble, R., and van der Wolf, J. 2020a. Molecular characterization of Pseudomonas from Agaricus bisporus caps reveal novel blotch pathogens in Western Europe. BMC Genomics 21:505.

Taparia, T., Krijger, M., Hodgetts, J., Hendriks, M., Elphinstone, J. G., and van de Wolf, J. 2020b. Six Multiplex TaqMan ${ }^{\text {TM }}$-qPCR assays for quantitative diagnostics of Pseudomonas species causative of bacterial blotch diseases of mushrooms. Front. Microbiol. 11:989.

Tolaas, A. G. 1915. A bacterial disease of cultivated mushrooms. Phytopathology 5:U51-U55.

Wells, J. M., Sapers, G. M., Fett, W. F., Butterfield, J. E., Jones, J. B., Bouzar, H. and Miller, F. C. 1996. Postharvest discoloration of the cultivated mushroom Agaricus bisporus caused by Pseudomonas tolaasii, P. 'reactans', and $P$. 'gingeri'. Phytopathology 86:1098-1104.

Wickham, H., Averick, M., Bryan, J., Chang, W., McGowan, L., François, R. Grolemund, G., Hayes, A., Henry, L., Hester, J., Kuhn, M., Pedersen, T. L. Miller, E., Milton Bache, S., Müller, K., Ooms, J., Robinson, D., Seidel, D. P., Spinu, V., Takahashi, K., Vaughan, D., Wilke, C., Woo, K., and Yutani, H. 2019. Welcome to the Tidyverse. J. Open Source Softw. 4.

Wickham, H., Chang, W., Henry, L., Takahashi, K., Wilke, C., Woo, K., Yutani, H., and Dunnington, D. 2016. ggplot2: Create Elegant Data Visualisations Using the Grammar of Graphics, Version 2. https:/ggplot2.tidyverse.org/ reference/ggplot2-package.html

Wong, W. C., Fletcher, J. T., Unsworth, B. A., and Preece, T. F. 1982. A note on ginger blotch, a new bacterial disease of the cultivated mushroom, Agaricus bisporus. J. Appl. Bacteriol. 52:43-48.

Wong, W. C., and Preece, T. F. 1980. Pseudomonas tolaasii in mushroom crops: A note on primary and secondary sources of the bacterium on a commercial farm in England. J. Appl. Bacteriol. 49:305-314.

Wong, W. C., and Preece, T. F. 1982. Pseudomonas tolaasii in cultivated mushroom (Agaricus bisporus) crops: Numbers of the bacterium and symptom development on mushrooms grown in various environments after artificial inoculation. J. Appl. Bacteriol. 53:87-96.

Wuest, P. J. 1971. Use of dew point and ambient temperature differences to explain epidemic development of mushroom bacterial blotch. Phytopathology 61:918. 